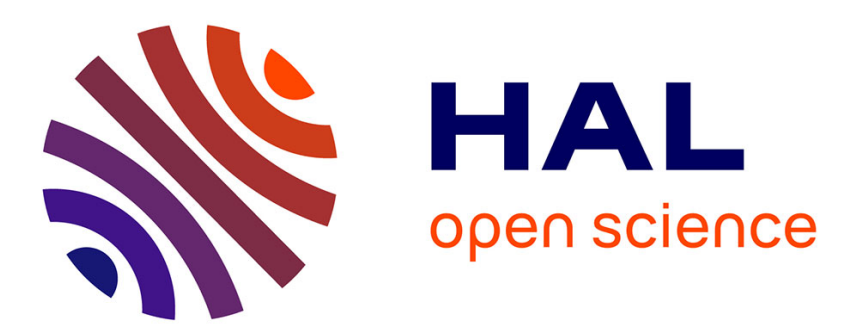

\title{
Variations in levels of clonality among Populus nigra L. stands of different ages
}

Nadia Barsoum, Etienne Muller, Leif Skot

\section{To cite this version:}

Nadia Barsoum, Etienne Muller, Leif Skot. Variations in levels of clonality among Populus nigra L. stands of different ages. Evolutionary Ecology, 2004, vol. 18 ( $\left.\mathrm{n}^{\circ} 5\right)$, pp. 601-624. 10.1007/s10682004-5146-4 . hal-01520598

\section{HAL Id: hal-01520598 \\ https://hal.science/hal-01520598}

Submitted on 10 May 2017

HAL is a multi-disciplinary open access archive for the deposit and dissemination of scientific research documents, whether they are published or not. The documents may come from teaching and research institutions in France or abroad, or from public or private research centers.
L'archive ouverte pluridisciplinaire HAL, est destinée au dépôt et à la diffusion de documents scientifiques de niveau recherche, publiés ou non, émanant des établissements d'enseignement et de recherche français ou étrangers, des laboratoires publics ou privés. 


\section{Open Archive TOULOUSE Archive Ouverte (OATAO)}

OATAO is an open access repository that collects the work of Toulouse researchers and makes it freely available over the web where possible.

This is an author-deposited version published in : http://oatao.univ-toulouse.fr/ Eprints ID : 4402

To link to this article : DOI : 10.1007/s10682-004-5146-4 URL : http://dx.doi.org/10.1007/s10682-004-5146-4

To cite this version : Barsoum, Nadia and Muller, Etienne and Skot, Leif Variations in levels of clonality among Populus nigra L. stands of different ages. (2005) Evolutionary Ecology, vol.18, n5-6, pp. 601-624. ISSN 0269-7653

Any correspondence concerning this service should be sent to the repository administrator: staff-oatao@listes-diff.inp-toulouse.fr 


\title{
Variations in levels of clonality among Populus nigra $\mathbf{L}$. stands of different ages
}

\author{
NADIA BARSOUM ${ }^{1, *}$, ETIENNE MULLER $^{1}$ and LEIF SKOT ${ }^{2}$ \\ ${ }^{1}$ CNRS - Laboratoire Dynamique de la Biodiversité, 29 rue Jeanne Marvig, 31055, Toulouse, Cedex \\ 4, France (*author for correspondence, tel.: +44-1420-526219; e-mail: nadia.barsoum@forestry.gsi. \\ gov.uk); ${ }^{2}$ Institute of Grassland and Environmental Research (IGER), Plas Gogerddan, Aberystwyth, \\ Ceredigion SY23 3EB Wales, UK
}

Co-ordinating editor: J. Tuomi

\begin{abstract}
The evolution of genotypic diversity with population age remains poorly explored in clonal plant populations despite the potential for important shifts to occur through the course of time. Woody sprouting species are particularly under-represented in studies investigating intraspecific variations in levels of clonality from one locality to the next and through time. In this study we sought to determine the incidence and frequency of replicate genotypes in natural Populus nigra L. (Salicaceae) stands of different ages. Ten stands of this woody riparian sprouting species were selected in each of three distinct age groups ('young', 'middle-aged' and 'old') along a $30 \mathrm{~km}$ stretch of the River Garonne (south-west France). Leaf samples were collected from 15 neighbouring trees in each stand (450 samples in total) and replicate genotypes were identified using five SSR markers. Replicate genotypes were identified in two-thirds of all stands sampled (i.e. $50 \%$ of young stands, $100 \%$ of middle-aged stands and $50 \%$ of old stands). Young stands had significantly fewer replicated genotypes than middle-aged or old stands, while middle-aged stands had the greatest number of replicated genotypes. Replicate genotypes were most often found to occur as nearest neighbours and formed relatively small, discrete units (i.e. 2-4 trees growing in close proximity to one another). This suggests that asexual regeneration frequently occurs through flood-training in this species, although asexual regeneration from translocated fragments also evidently occurs as evidenced by 11 cases of replicate genotypes occurring in widely separated stands (up to $19 \mathrm{~km}$ apart). The results of this study highlight the need for a hierarchical sampling strategy in space and across age groups for an accureate understanding of the genotypic structure of woody sprouting species populations. Conservation and management of effective population sizes will benefit from better insight into not only spatial, but also temporal variations in levels of genotypic diversity.
\end{abstract}

Key words: age, clone, Garonne River, genotypic diversity, microsatellite, Populus nigra

\section{Introduction}

An appreciation of spatio-temporal variations in the relative contributions of sexual and asexual recruitment in plant species known to utilise both regeneration strategies, is a fundamental prerequisite to understanding the genetic structure and dynamics of populations of such species. In certain respects, asexual regeneration can be considered an advantageous strategy in that it may (i) confer certain competitive physiological advantages (e.g. shared resources, 
or growth forms with improved resistance to inter- and con-specific competitors) and (ii) favour the persistence of given genotypes in a population, leading in many cases to reduced demographic turnover rates at the level of the entire population (Wilson et al., 1985; De Steven, 1989; Caraco and Kelly, 1991; Jelinski and Cheliak, 1992; Stuefer, 1998). Examples include numerous woody sprouters such as Tilia cordata and Populus tremuloides, known to have genotypes with generation times that exceed several millennia (Kemperman and Barnes, 1976; Pigott, 1993). However, asexual recruitment has also been associated with reduced survivorship of asexual compared with sexual offspring in certain clonal plant species (Paciorek et al., 2000). Furthermore, intense clonal replication may lead to a decline in a population's capacity to reproduce sexually where resources are diverted to maintaining growth among vegetative recruits (Keeley, 1977; Henderson, 1991; Iwasa and Kubo, 1997) and/or where unbalanced sex ratios develop in dioecious species (Shafroth et al., 1994; Gom and Rood, 1999). A significant reduction in genotypic diversity is another potentially negative consequence, especially where no growth strategies (e.g. 'phalanx', or 'guerrilla' growth habits) are in place to counter-act such a loss as exists in certain clonal plant species (Schmid, 1985; Maddox et al., 1989). The result may be a reduction in effective population sizes with a concomitant decline in fitness and adaptability in the long term to unpredictable changes in the environment (e.g. disease, climate change) (Williams, 1975; Muirhead and Lande, 1997).

Genetic techniques offer increasingly powerful means of identifying identical genotypes within a population and have been applied to this effect in numerous clonal plant studies (Parker and Hamrick, 1992; Widén et al., 1994; Escavarge et al., 1998; Kreher et al., 2000). Limited use has been made of genetic techniques, however, to investigate the strength of relationships between factors (intrinsic or external) that may influence the relative proportions of sexual to asexual recruits (Eriksson and Bremer, 1993; Mandujano et al., 1998; Kudoh et al., 1999; Dorken and Eckert, 2001). Even fewer studies provide insight into how the genotypic diversity of a clonal plant population evolves with population age (but see Maddox et al., 1989) and only one study is known to have applied genetic techniques to this end (Cronberg, 2002). Woody sprouting species are particularly under-represented in studies investigating intra-specific variations in patterns of sexual and asexual recruitment.

Vegetative regeneration by sprouting is frequently observed in pioneer woody plants growing in environments subject to natural cycles of disturbance (e.g. hurricane or fire prone habitats, floodplains, at high altitudes and latitudes, etc.). Vegetative shoots or 'ramets' are typically stimulated to grow in response to external environmental stimuli of biotic or abiotic origin (e.g. floods, grazing, fire, high winds) and of variable intensities, although availability of resources has also been known to have an effect on levels of 
asexual recruitment in certain woody sprouting species (Shafroth et al., 1994; Read and Brown, 1996; Kruger et al., 1997; Barsoum and Hughes, 1998). Vegetative shoots may grow either as extensions of the parent plant, where root or shoot connections remain intact. They may also grow independently of the parent plant, where any connections disintegrate over time, or vigorous fragments of the parental plant are translocated to a new location with favourable growing conditions by floodwaters, animals or the wind.

Sprouting intensity reflects typical levels of exposure to disturbance. One might expect, therefore, considerable spatio-temporal heterogeneity in levels of genotypic diversity both within and between populations of the same species where resources/disturbances are themselves not equally distributed in space and time (Held, 1983; Rood et al., 1994; McKay, 1996; Gom and Rood, 1999; Tardif and Bergeron, 1999; Barsoum, 2002). Clearly defined relationships between levels of sprouting in clonal woody species (as reflected by levels of genotypic diversity) and environmental factors that promote sprouting are, nevertheless, very difficult to establish. Firstly, as relatively long-lived perennial species, woody sprouters will typically experience significant changes in disturbance regimes and/or resource availability throughout their lifecycle (Faliñska, 1995). Secondly, the physiological response of woody sprouters to external stimuli is also likely to change at different stages in the plants life cycle (Read, 1958; Malanson and Trabaud, 1988, De Steven, 1989). Finally, factors promoting sprouting may intervene at repeated intervals such that their effects become accumulative; in this case, genotypic diversity will depend on the history of disturbance/resource availability. Barsoum (2002) highlighted, for instance, a gradual rise in the relative proportion of asexual to sexual recruits in the floodplain woodland species Populus nigra L. during the first 4 years of its life cycle, resulting from both the loss of some genets and the vegetative expansion of others with each successive wave of flood disturbance.

Certain discrepancies exist between what is observed and what is expected with regards to evolving trends in levels of woody sprouter genotypic diversity through time. As recruitment from seedlings is considered to be rare in established populations of most forest-growing clonal vascular plants (Eriksson, 1989), genotypic diversity can be expected to decline through the course of time according to Eriksson's Initial Seedling Recruitment model; this model is supported by Hermanutz et al. (1989) in their observations of low genotypic diversity in established populations of the arctic dwarf birch (Betula glandulosa). Alternative scenarios propose that genotypic diversity following initial seedling recruitment can in fact be maintained in woody sprouting species. This is explained either by (i) expected inter-ramet competition for resources (e.g. following canopy closure) leading to reduced survivorship of asexual offspring and, thus a decline in the number of identical genotypes in a population (Peterson and Jones, 1997), (ii) microsite heterogeneity that 
promotes co-existence of genotypes (Ellstrand and Roose, 1987), and/or (iii) 'windows of opportunity' for seedling recruitment emerging to replenish genet variety in established populations (e.g. Jelinski and Cheliak, 1992) as Eriksson's more recently conceived Repeated Windows of Opportunity predictive model proposes (Eriksson, 1997).

In the present study, we hypothesised that the stochastic element inherent in flood disturbances would produce significant variability in levels of re-sprouting (and therefore genotypic diversity) between similar-aged Populus nigra $\mathrm{L}$. stands and highly localised clonal expansion through sprouting from flood-trained branches and roots of damaged trees. We expected also that following initial seedling recruitment events, the number of unique genotypes will tend to decline with the age of the stands where (i) successive flood disturbances promote vegetative expansion of surviving genets and (ii) competitive interactions among established genotypes act to favour the fittest genotypes. To test these hypotheses, we applied molecular genetic techniques to assess the incidence of clonal replication in P. nigra across multiple, widely distributed stands of uniform age distributed in three distinct age categories (young, middle-aged and old). Previous genetic studies in this species have revealed widely contrasting results in the frequency of replicated genotypes present in populations (Legionnet et al., 1996; Arens et al., 1998; Smulders et al., 2002).

\section{Materials and methods}

\section{Study species}

The black poplar, Populus nigra (L.), is a dioecious, diploid tree species occurring along rivers with relatively free-draining substrates throughout Continental Europe, where it often dominates the active zone of alluvial plains and plays an important role in stabilising sites recently disturbed by flooding (Barsoum, 2001). Despite having a breeding system designed to maximise sexual recruitment (an out-crosser with high fecundity and very high production of germinable, wind-dispersed seeds, timed for release from May to mid-June to coincide with the abatement of spring floods), frequent and unpredictable flood disturbances on the natural floodplain, followed by rapidly declining water table levels, provide a narrow window of opportunity for recruitment from short-lived seeds such that several years may go by before ideal conditions for recruitment present themselves (Van Splunder et al., 1996; Barsoum 2002). Intolerant of shade, P. nigra seedlings colonise bare sand and gravel bars where they often develop into dense monospecific stands with no further seedling recruitment possible in the under-storey. Vegetative regener- 
ation, as an alternative regeneration strategy, is promoted through extended periods of submergence and/or mechanical damage to parental plants that act to stimulate dormant primordia in roots or shoots (Legionnet et al., 1997; Barsoum, 2002).

\section{Study sites}

The P. nigra stands sampled were patchily distributed along an approximately $30 \mathrm{~km}$ stretch of the River Garonne some $25 \mathrm{~km}$ downstream of the city of Toulouse, in south-west France (between $44^{\circ} 15^{\prime} \mathrm{N}$ and $1^{\circ} 15^{\prime} \mathrm{E}$; $90 \mathrm{~m}$ a.s.l.). The stands are remnants of former large expanses of $P$. nigra-dominated floodplain forest (i.e. present coverage is $19 \%$ of the surface area occupied in 1810). Much of the woodland was lost following trends for widespread cultivation of hybrid poplars since the 1800s' and a two-third reduction in the rivers active zone with the construction of embankments in the 1970s' (Muller et al., 2002). Gravel extraction from within the river channel and the construction of dams along the River Garonne between the 1970s' and 1990s' have contributed further to the loss and transformation of poplar recruitment sites through a reduction in the availability of bed material. Related 'knock-on' effects have included significant incision of the riverbed (1-3 m over the past 50 years), a gradual hydrological disconnection of raised sections of the greater floodplain, beyond the active channel, and faster flow rates in an increasingly channelised riverbed (Steiger et al., 2001). Today self-sustaining populations of $P$. nigra are thus largely confined to the active channel where despite more intense flow rates than in the past, flood disturbances still create ideal recruitment sites and hydric conditions that are favourable for regeneration and rapid growth (Guilloy-Froget et al., 2002).

Geomorphic units colonised by $P$. nigra within the active zone included islands, former side channels, and narrow, elongated point bars along the riverbank. Intensity of flood disturbance at any of these geomorphic units varied depending on its situation within the active river channel and temporal variations in the direction of river flow. At the lower elevations, where tree establishment occurred, young P. nigra typically formed monospecific stands, although occasionally could be found coexisting with white willow (Salix alba L.). Older $P$. nigra stands, having survived successive waves of sedimentation, were located at higher elevations in the active alluvial zone either on islands or along the riverbank where they were gradually infiltrated by later successional woodland species such as Alnus glutinosa, Fraxinus excelsior and the exotic species Acer negundo and Robinia pseudacacia. Evidence of past disturbance was sometimes apparent in older stands from debris trapped on tree trunks, leaning trees and clumped, coppice-like growth. 
In the study area, the climate can be described as warm temperate (mean annual temperature of $12.7^{\circ} \mathrm{C}$ ), influenced by elements of both Mediterranean and Atlantic climates with mean annual rainfall in the order of $706 \mathrm{~mm} \pm 38$ (1988-2002) (Météo France, Toulouse). Mean annual discharge is $199 \mathrm{~m}^{3}$ $\mathrm{s}^{-1} \pm 35$, reaching peaks of $1440 \mathrm{~m}^{3} \mathrm{~s}^{-1}$ during normal annual floods. Floods typically occur in the winter (most frequently in December) and in the spring (most frequently in April and May), although significant flooding events can also occur outside of these periods. Over the 1973-2001 period, maximum annual discharge ranged from 486 to $2926 \mathrm{~m}^{3} \mathrm{~s}^{-1}$ and on five occasions over the period in question, exceeded $2000 \mathrm{~m}^{3} \mathrm{~s}^{-1}$ (discharge levels 10 times greater than the annual discharge) (DIREN, Toulouse).

\section{Sampling procedure}

Following a preliminary pilot survey of the range of even-aged homogenous $P$. nigra stands present along the $30 \mathrm{~km}$ study reach, three distinct age groups ('young', 'middle-aged' and 'old') were selected according to stem diameter and plant height. The very few existing stands estimated to be older than 30 years were not sampled since trees in these stands were considered to have been recruited before the construction of embankments in the 1970's; i.e. under hydrological and sedimentological conditions no longer in existence. First year seedlings were also omitted from the study since these have very low annual survivorship and as such, represent only a fleeting genetic contribution to the population (Johnson, 1994; Cooper et al., 1999; Guilloy-Froget, 2002; Guilloy-Froget et al., 2002; Barsoum, 2002). In each age category 10 stands with a minimum of 30 individuals present were selected to cover the variety of geomorphological settings in which they occurred along the $30 \mathrm{~km}$ study reach (Table 1; Fig. 1).

Since asexual regeneration of $P$. nigra appeared to occur most frequently following flood-training of branches and trunks along the River Garonne, a nearest neighbour sampling strategy was adopted. In each stand, 15 saplings/ trees were selected by first tagging one individual and then 14 of its nearest neighbours estimated to occur either perpendicularly or in a downstream trajectory to this individual with respect to river flow. In many cases, successive flood disturbances provoked re-sprouting at the base of the tree trunks, resulting in clumped growth. To resolve this sampling problem, the stem with the greatest diameter in a clump was always selected. Also, to reduce the chances of including a re-sprouted stem as a nearest neighbour, in each age group any stems with diameters below a fixed minimum value were excluded and a minimum distance to nearest neighbours was assigned. Thus, trees were not sampled if their stem diameter at ground level was inferior or equal to $2.5 \mathrm{~cm}$ in young stands, $5 \mathrm{~cm}$ in middle-aged stands and $10 \mathrm{~cm}$ in old stands 
Table 1. Description of sample stands along the River Garonne

\begin{tabular}{|c|c|c|c|}
\hline $\begin{array}{l}\text { Stand reference } \\
\text { No. }\end{array}$ & $\begin{array}{l}\text { Topographic } \\
\text { setting }\end{array}$ & $\begin{array}{l}\text { Present position } \\
\text { on bar or island }\end{array}$ & $\begin{array}{l}\text { Width of bar or island } \\
\text { (narrow } \leq 10 \mathrm{~m} \text {; wide }>10 \mathrm{~m} \text { ) }\end{array}$ \\
\hline \multicolumn{4}{|l|}{ Young } \\
\hline 1 & Gravel bar & Centre & Narrow \\
\hline 2 & Gravel bar & Upstream end & Narrow \\
\hline 3 & Gravel bar & Upstream end & Wide \\
\hline 4 & Gravel bar & Centre & Narrow \\
\hline 5 & Gravel bar & Centre & Narrow \\
\hline 6 & Island & Upstream end & Narrow \\
\hline 7 & Gravel bar & Upstream end & Narrow \\
\hline 8 & Island & Downstream end & Narrow \\
\hline 9 & Gravel bar & Downstream end & Wide \\
\hline 10 & Gravel bar & Centre & Narrow \\
\hline \multicolumn{4}{|l|}{ Middle-aged } \\
\hline 1 & Gravel bar & Centre & Narrow \\
\hline 2 & Gravel bar & Centre & Wide \\
\hline 3 & Gravel bar & Centre & Narrow \\
\hline 4 & Gravel bar & Centre & Wide \\
\hline 5 & Side channel & Centre & Wide \\
\hline 6 & Island & Centre & Wide \\
\hline 7 & Island & Downstream end & Narrow \\
\hline 8 & Gravel bar & Downstream end & Narrow \\
\hline 9 & Island & Upstream and & Wide \\
\hline 10 & Side channel & Mid reaches & Narrow \\
\hline \multicolumn{4}{|l|}{ Old } \\
\hline 1 & Island & Centre & Wide \\
\hline 2 & Island & Downstream end & Wide \\
\hline 3 & Island & Centre & Wide \\
\hline 4 & Gravel bar & Downstream end & Wide \\
\hline 5 & Gravel bar & Centre & Wide \\
\hline 6 & Gravel bar & Downstream end & Wide \\
\hline 7 & Island & Centre & Wide \\
\hline 8 & Island & Downstream end & Wide \\
\hline 9 & Lateral bench & Centre & Narrow \\
\hline 10 & Gravel bar & Centre & Wide \\
\hline
\end{tabular}

and minimum distances to nearest neighbours were $25 \mathrm{~cm}$ in the young stands, $50 \mathrm{~cm}$ in the middle-age stands and $100 \mathrm{~cm}$ in the old stands; any trees within the minimum distance range were considered to comprise the clumped growth of a tagged tree.

\section{Descriptive parameters}

In addition to sample selection, the characteristics of each stand were evaluated using seven descriptive parameters, each highlighting ecological differences between stands. Based on measurements of the 15 tagged trees in each stand, these included: stand density, tallest shoot height, stem diameter at ground 


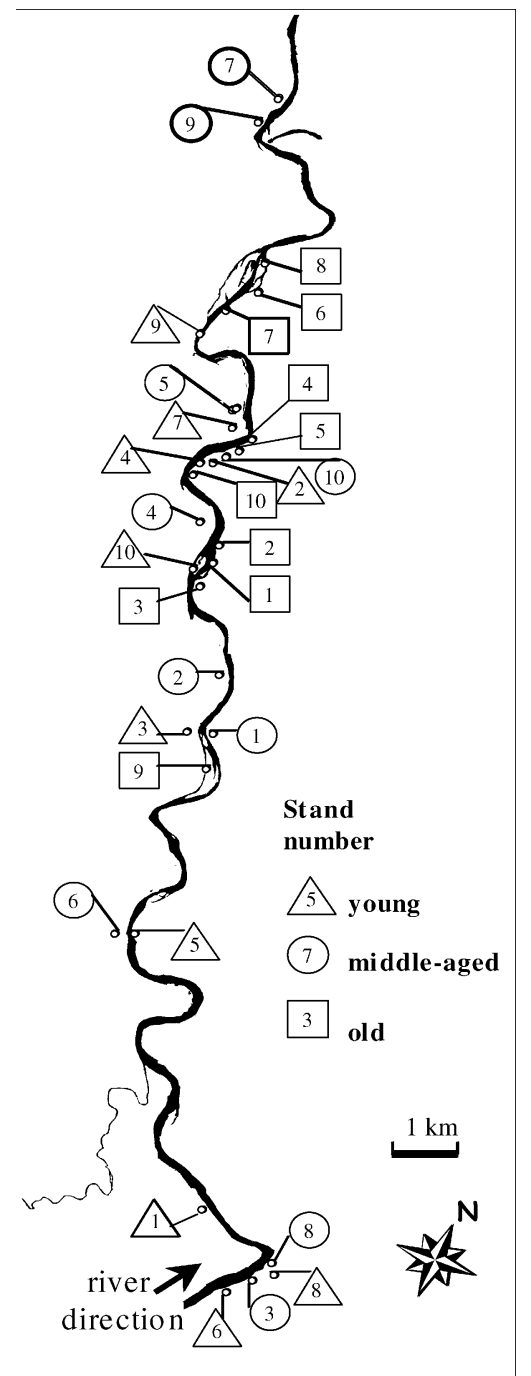

Figure 1. Locations of the young, middle-aged and old P. nigra stands sampled along the River Garonne study reach. Numbers inside symbols correspond to the stand number (1-10) in each age group.

level, incidence of clumped growth (i.e. number of tagged trees in stand displaying clumped growth), clump sizes (number of stems per clump), angle of slant of trunks from the original vertical position and tree age. Stand density $\left(D-\right.$ number of trees per $\mathrm{m}^{2}$ ) was estimated in each stand using a plotless method (Engeman et al., 1994). This involved measuring the distances between the first tagged individual originally selected in the stand and each of its closest 
14 neighbours. Stand density was then calculated based on an estimate of the number of stems in a semi-circular area containing the nearest 14 trees,

$$
D=(15-1) \mid(\pi r 2 / 2)
$$

where $r$ is the mean of the distances between the first individual tagged and its 14 nearest neighbours. The validity of stem diameter and clumped growth measurements as stand descriptors was tested by enlarging the sample size in each stand through the random selection of 15 additional nearby trees. Estimates of stand age were determined by harvesting a single tree of average stem diameter in each stand and counting annual rings in cross-section. To avoid felling of trees in a number of the old stands, tree cores were collected instead for estimates of stand age.

\section{Collection of plant material and DNA extraction}

Cuttings were collected (March-May, 2002) from the 15 tagged trees in each of the 30 selected stands $(15 \times 30=450$ trees $)$. Additional cuttings were collected in the 10 'old' stands, from any stems comprising a clump of each of the 15 tagged trees. This latter additional sample collection served to (i) verify whether clumped growth corresponds to re-sprouting from a single plant and thus, numerous clonal replicates at a single sampling point and, where this is true, (ii) to assess the potential contribution of multiple replicated genotypes in a clump to overall genotypic diversity in mature stands where these replicates appear to have good chances of survival. Once collected, the cuttings were transferred on the same day to water-filled basins installed in a warm, well-lit room. One to two weeks later, $2 \times 50 \mathrm{mg}$ of freshly emerged leaves were harvested from the available cuttings to provide two replicate leaf samples for each sampled tree. On collection, the leaf material was immediately desiccated using silica gel and stored in an airtight container for a maximum of one week at room temperature before extraction of total nuclear DNA using the DNeasy ${ }^{\circledR} 96$ Plant Kit. The presence and integrity of DNA in each sample was verified by agarose gel electrophoresis, and in cases where no DNA was detected, DNA was extracted from a replicate leaf sample.

\section{Microsatellite analyses}

Microsatellites were favoured in this study as the most sensitive markers for clonal identification in this species (Smulders et al., 2002; Strome et al., 2002; Cottrell et al., 2002). Five microsatellite loci (all dinucleotide repeats) that had previously been shown to display easy to score band patterns and a high level of polymorphism in P. nigra (Van der Schoot et al., 2000), were selected for the identification of identical genotypes (Table 2). These were amplified using an ABI 9700 thermal cycler according to the PCR programmes described by Van 
der Schoot et al. (2000) and the amplified products were separated by capillary electrophoresis using the ABI 3100 PRISM $^{\circledR}$ Genetic Analyzer. The sizes of the fluorescent PCR products and raw data output were saved automatically using Genescan 3.7 software and analysed using the Genotyper 3.7 programme. The automated binning of products into allelic categories was checked by visual inspection of electropherograms.

The reproducibility of the analyses was assessed by extracting and analysing 48 replicate samples with two of the five SSR primer pairs. Furthermore, several randomly selected samples were blindly replicated and run twice. Replicate samples in all except one case yielded identical base pair sizes at all five loci; the exception varied in size by one base pair at a single locus. This could be attributed to the automatic rounding of base pair sizes.

\section{Allelic diversity of microsatellite loci}

The total number of possible alleles at each locus and the base pair size ranges of these are given in Table 2 as found in this study and as reported in the original publication that first described these loci (Van der Schoot et al., 2000). This study recorded at least twice as many alleles at all loci except at WPMS12, although allelic ranges remained very similar; this may simply reflect the greater sample size in this study (Van Dam and Boracs, 2002).

The high number of alleles per locus (between 12 and 32 alleles) and wide allelic ranges among these, suggests that all five microsatellite loci scored in this study were highly polymorphic, with WPMS03 and WPMS07 being the most polymorphic and WPMS12 the least. When the number of genotypes is plotted against the number of microsatellite loci used for scoring distinct genotypes, the five loci selected for this study were found to adequately cover the polymorphism present in the Garonne population; i.e. the average (standard

Table 2. Comparison of the number of alleles and allelic ranges obtained in this study and in the original publication that first described the microsatellite loci WPMS03, WPMS05, WPMS07, WPMS09, WPMS12 in P. nigra

\begin{tabular}{|c|c|c|c|c|c|}
\hline \multirow{2}{*}{$\begin{array}{l}\text { Microsatellite } \\
\text { locus }\end{array}$} & \multirow{2}{*}{$\begin{array}{l}\text { Repeat } \\
\text { motif }\end{array}$} & \multicolumn{2}{|l|}{ This study } & \multicolumn{2}{|c|}{ Van der School et al. (2000) } \\
\hline & & Number of alleles & Allelic range & Number of alleles & Allelic range \\
\hline WPMS03 & $(\mathrm{GT}) 26-1$ & 31 & $257-308$ & 15 & $262-302$ \\
\hline WPMS05 & $(\mathrm{GT}) 27$ & 20 & $258-302$ & 13 & $270-308$ \\
\hline WPMS07 & $(\mathrm{GT}) 19$ & 32 & $212-268$ & 12 & $218-270$ \\
\hline WPMS09 & $(\mathrm{GT}) 24$ & 21 & $214-286$ & 11 & $246-298$ \\
\hline \multirow[t]{4}{*}{ WPMS12 } & $(\mathrm{GT}) 21(\mathrm{GA}) 24$ & 12 & $157-179$ & 10 & $157-183$ \\
\hline & & Mean $=24.4$ & & Mean $=12.2$ & \\
\hline & & $\mathrm{SD}=8.1$ & & $\mathrm{SD}=1.9$ & \\
\hline & & $N=449$ & & $N=23$ & \\
\hline
\end{tabular}


deviation) number of genotypes detected in the sample population by one, two, three, four and five microsatellite loci were respectively, 88 (53), 296 (58), 380 (5), 391 (2) and 397 (-). Scoring of identical genotypes for this latter exercise depended on two different samples having identical base pair sizes at all loci being tested; absence of a single base pair at a given locus in one, but not in another otherwise identical sample, or single digit differences in allele sizes were interpreted as indicators of differentiation between a pair of samples and thus the two samples were considered to represent two different genotypes.

Scoring for the identification of identical genotypes in the 30 stands for the purposes of this study was equally rigorous, although some allowance was made for the possibility of ambiguities in the scoring of alleles; that is, identical genotypes were recorded where allele sizes at all five microsatellite loci were identical or where there was one base pair size difference in alleles at no more than a single locus. Within each stand, trees were identified either as (i) 'unique genotypes' where no other trees within the sample population (450) had the same allele sizes at all five microsatellite loci tested, or (ii) 'replicated genotypes' (ramets) where allele sizes at the five microsatellite loci tested were found to be identical with another tree(s) in the sample population; all replicated genotypes, or ramets of the same genotype made up a 'clone'. By combining the number of unique genotypes and the number of clonal genotypes present in each stand, the total number of different genotypes per stand was derived.

\section{Data analyses}

One-way ANOVAs were applied to test for significant differences between the 'young', 'middle-aged' and 'old' stands in terms of stand density, shoot height, stem diameter, angle of stem slant and incidence and intensity of clumped growth following $\log$ transformation of the data sets and Anderson-Darling and Levene's tests for normal distributions and equal variances, respectively (Minitab Release 14). Where significant differences were found, inter-age comparisons of means were tested for significant differences by applying Tukey tests.

Kruskal-Wallis tests followed by Mann-Whitney pair wise comparisons were applied to test for significant differences in young, middle-aged and old stands in terms of: (1) the number of different genotypes present in each stand, (2) the total number of clones in each stand and (3) the number of replicated genotypes (clone sizes) in each stand. These analyses were first undertaken considering only the 15 trees sampled in each stand and subsequently included all additional stems comprising the clumped growth of sampled trees in order to estimate their respective genotypic contribution to stands; the assumption was made that the stems making up the clumped growth of the sampled trees 
represented identical and viable genotypes that contributed to total genotypic variation in each stand and stands were therefore compared as such.

Relationships between potential indicators of stand disturbance (i.e. angle of slant of trees, incidence and magnitude of clumped growth) and the incidence and frequency of replicated genotypes within stands in each age group $(0=$ no replication; $1=1$ replica; $2=2$ replicas, etc.) were investigated using Pearson's correlation coefficient. The three stand descriptors were log transformed and the counts of the number of replicated genotypes within stands in each age group were square root transformed prior to analysis to meet assumptions of normally distributed data sets and equal variances; these were tested using the Anderson-Darling and Levene's tests.

\section{Results}

\section{Stand characteristics}

Examination of annual rings on tree sections, indicated that tree ages in the 'young', 'middle-aged' and 'old' stands were on average $5.6( \pm 1.4), 8( \pm 1.6)$ and $17.6( \pm 2.5)$, respectively. Differences in mean log stand densities, log heights of tallest shoots and $\log$ stem diameters were highly significant $(p<0.001)$ between stand age categories, with the exception of no significant difference between middle-aged and old stand densities (Table 3).

Trees in the middle-aged stands frequently displayed moderate to severe leaning as a consequence of repeated periods of strong and continuous river

Table 3. P. nigra stand characteristics

\begin{tabular}{|c|c|c|c|c|c|c|c|}
\hline & Young & Middle-aged & Old & d.f. & MS & $\mathrm{F}$ & $\mathrm{P}$ \\
\hline \multicolumn{8}{|c|}{ Descriptor at stand level ( $n=30$ stands) } \\
\hline Stand density (no. $/ \mathrm{m}^{2}$ ) & $1.7(0.9)^{\mathrm{a}}$ & $0.5(0.2)^{\mathrm{b}}$ & $0.2(0.1)^{\mathrm{b}}$ & 27 & 0.08 & 34.09 & $* * *$ \\
\hline Incidence of clumped growth & $4.1(3.5)$ & $5.0(3.5)$ & $4.1(3.4)$ & 27 & 0.15 & 0.32 & n.s. \\
\hline \multicolumn{8}{|c|}{ Descriptor of trees sampled $(n=450)$} \\
\hline Tree height $(\mathrm{m})$ & $4.8(1.8)^{\mathrm{a}}$ & $5.6(2.2)^{\mathrm{b}}$ & $17.9(2.3)^{\mathrm{c}}$ & 447 & 0.028 & 11.40 & $* * *$ \\
\hline Stem diameter $(\mathrm{cm})$ & $5.4(2.6)^{\mathrm{a}}$ & $10.8(4.9)^{\mathrm{b}}$ & $27.4(10.9)^{\mathrm{c}}$ & 447 & 0.03 & 559.82 & $* * *$ \\
\hline Angle of slant of stem (degrees) & $29.1(21.1)^{\mathrm{a}}$ & $51.6(25.2)^{\mathrm{b}}$ & $3.3(7.4)^{\mathrm{c}}$ & 447 & 0.33 & 219.76 & $* * *$ \\
\hline \multicolumn{8}{|c|}{ Descriptor of trees sampled displaying clumped growth $(n=130)$} \\
\hline $\begin{array}{l}\text { Clump size where clumped } \\
\text { growth occurs }\end{array}$ & $1.5(1.0)$ & $1.8(1.6)$ & $2.1(1.6)$ & 127 & 0.33 & 1.58 & n.s. \\
\hline
\end{tabular}

Means and standard deviations (in parentheses) are given for the range of stand descriptors measured in this study for the $15 \times 10$ sampled trees in each age group. A one-way ANOVA tested for significant differences $\left({ }^{* * *} p<0.001\right)$ between age groups following log transformation of each measured parameter. Different characters indicate significant inter-age group differences $(p<0.001)$ based on Tukey tests. Mean clump number and clump size include all stems making up the clump excluding the tagged tree. 
flow against the tree trunks during periods of high discharge; e.g. in one middle-aged stand, situated on an island, many tree trunks were completely prostrate. This leaning in middle-aged stands contrasted significantly $(p<0.001)$ both with saplings growing in the youngest stands, where moderate to almost no leaning was observed, and with trees growing in the oldest stands, where the majority of trees were growing vertically (Table 3 ).

Clumped growth featured in some stands, but not in others; i.e. in $50 \%$ of all stands sampled, clumped growth was observed in $0-3$ of the 15 trees sampled, while in the remaining $50 \%$ of stands, clumped growth was displayed by 4-11 of the 15 sampled trees. This was the case for stands in all three age categories as is evidenced by high levels of standard deviation around the means for incidence of clumped growth (Table 3). Where clumped growth did occur in a stand, there was substantial variation in the sizes of clumps in all age categories; i.e. $78 \%$ of the time clumps comprised 1-2 additional stems growing adjacent to sampled trees, while larger clumps comprising up to 11 additional stems were also observed. No age-related correlations were detected for either incidence of clumped growth or clump sizes (Table 3).

\section{Variations in levels of clonality among stands}

Where additional stems making up clumped growth are excluded from the analysis, it was found that a high proportion of the stands in each age category contained clones among the 15 sampled trees; i.e. $50 \%$ of young stands, $100 \%$ of middle-aged stands and $50 \%$ of old stands. Considerable variation existed, however, both in terms of the number of clones and in the number of different genotypes present among stands of the same age category and particularly among old stands (Fig. 2a and Table 4). Despite this variability within age groups, significant differences were nevertheless detected for these parameters between young, middle-aged and old stands. Concerning the number of clones present in stands of different ages, these were significantly $(p<0.05)$ more common in middle-aged than in young, or old stands with young stands having the least number of clones per stand (Fig. 2a). Clones were not sizeable in any of the age classes, each comprising two trees, or ramets on average with significantly $(p<0.05)$ more ramets found per tree in the middle-aged stands compared with the young and old stands (Fig. 2b). With respect to the number of different genotypes in each stand, mean values in young stands were significantly greater $(p<0.05)$ than in the middle-aged or old stands (Table 4) and there was no significant difference between middle-aged and old stands in this respect.

Consideration of the entire data set reveals that despite a high incidence of clones the total number of unique genotypes remains high; that is, out of 450 trees sampled, 351 represented unique genotypes (78\%), 98 represented 
(a)

Mean: $0.5^{\mathrm{a}}( \pm 0.17) \quad 2.1^{\mathrm{b}}( \pm 0.38) \quad 1.4^{\mathrm{ab}}( \pm 0.50)$

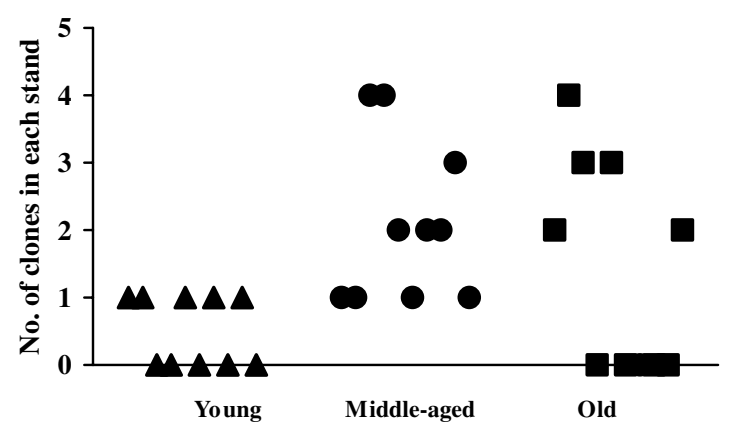

(b)

Mean: $2.0^{\mathrm{a}}( \pm 0.00) \quad 2.1^{\mathrm{b}}( \pm 0.07) \quad 2.3^{\mathrm{a}}(+0.19)$

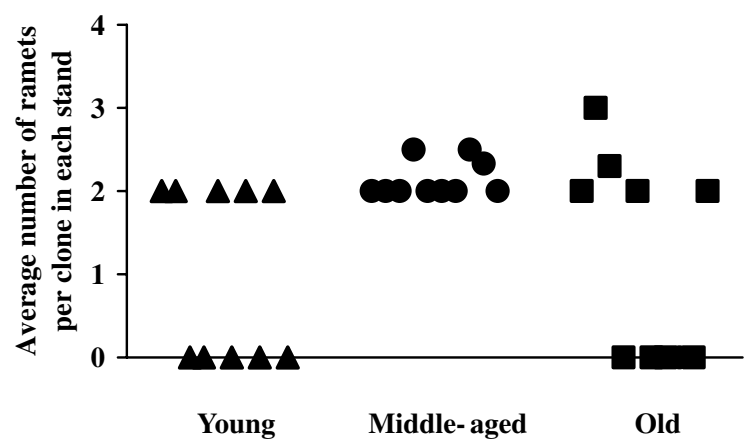

Figure 2. (a) Number of clones occurring in the 10 young, middle-aged and old $P$. nigra stands. (b) Number of ramets per clone in each of the 10 young, middle-aged and old P. nigra stands (stems in clumps excluded). Significant differences between age groups were tested by applying KruskalWallis tests followed by Mann-Whitney pairwise comparisons $(p<0.05)$. Different characters indicate significant inter-age group differences. Mean values are given with standard errors in parentheses.

replicated genotypes (22\%) and 1 sample yielded no results. The high numbers of unique genotypes, despite high apparent levels of clonality, is explained by low levels of replication of any given genotype within stands (Fig. 2b). Among all clones identified within stands, there were seven instances of three identical genotypes detected in the same stand and only one instance of four identical genotypes detected within the same stand.

Variations in levels of clonality among stands (stems in clumps included)

SSR analyses of the additional stems making up the clumped growth of sampled trees in old stands, revealed that in most cases (98\% of the time) these additional stems were identical to the tagged trees. Non-identical stems either 
Table 4. Number of different genotypes detected in the 10 young, middle-aged and old P. nigra

\begin{tabular}{llll} 
stands & & & \\
\hline Stand number & Young & Middle-aged & Old \\
\hline 1 & 14 & 14 & 13 \\
2 & 14 & 14 & 7 \\
3 & 15 & 11 & 11 \\
4 & 15 & 9 & 15 \\
5 & 14 & 13 & 15 \\
6 & 15 & 14 & 15 \\
7 & 14 & 13 & 15 \\
8 & 15 & 12 & 15 \\
9 & 14 & 11 & $12(14)^{*}$ \\
10 & 15 & 14 & $13.1^{\mathrm{b}}( \pm 0.83)$ \\
Mean & $14.5^{\mathrm{a}}( \pm 0.17)$ & $12.5^{\mathrm{b}}( \pm 0.54)$ &
\end{tabular}

Sample sizes comprised 15 trees in all stands with one exception $\left(^{*}\right)$ where the sample size was 14. Significant differences between age groups (indicated by different characters) were tested by applying a Kruskal-Wallis test followed by Mann-Whitney pairwise comparisons $(p<0.01)$. Mean values are given with standard errors in parentheses.

differed by up to two base pairs at a single locus (three cases) compared with the tagged tree, suggesting that slight mutations may have occurred in vegetative sprouts, or in three other instances, were clearly identified as different genotypes. Where the assumption is made then that all additional stems making up the clumped growth of sampled trees can be included as viable genotypes contributing to total genotypic variation in each stand, a highly significant difference $(p<0.001)$ emerges between young and middle-aged stands in terms of the frequency of replicated genotypes, with nearly three times more replicated genotypes present in middle-aged stands compared with young stands. Old stands were found to be intermediate between young and middle-aged stands and as such, no significant difference in the frequency of replicated genotypes was found between old stands and young or middle-aged stands. The average proportions ( $\%$ ) of different genotypes to stems sampled in the young, middle-aged and old stands revealed a considerable drop in the proportions of different genotypes present in stands where additional stems are included in the estimate (Table 5); the general trends of lowest levels of clonal replication in young stands and highest levels in middle-aged and old stands remain, nevertheless, the same.

\section{Spatial distribution of replicated genotypes (ramets)}

Trees comprising clones within stands were nearest neighbours $76 \%$ of the time. Distances separating ramets within the same stand ranged from up to $4 \mathrm{~m}$ in young stands, $5 \mathrm{~m}$ in middle-aged stands and $11 \mathrm{~m}$ in old stands. There were also 11 cases of ramets occurring in separate stands. The distances between 
Table 5. Average proportions (\%) of different genotypes to stems sampled in the young, middleaged and old stands

\begin{tabular}{llll}
\hline & \multicolumn{4}{c}{ Average proportions $(\%)$ of different genotypes to stems sampled } \\
\cline { 2 - 4 } & Young & Middle-aged & Old \\
\hline Stems in clumps excluded & 97 & 83 & 87 \\
Stems in clumps included & 75 & 56 & 64 \\
\hline
\end{tabular}

stands where ramets of the same clone were found, and hence approximate distances travelled by vegetative fragments, ranged from $226 \mathrm{~m}$ to $19 \mathrm{~km}$.

\section{Frequency of replicated genotypes and indicators of stand disturbance}

Table 6 lists the parameters tested as potential indicators of hydrological disturbance against the number of replicated genotypes in the young, middle-aged and old stands, the different age groups tested jointly and separately. As there was an element of doubt regarding the true cause of slanting of some tree trunks in the old stands (phototropic responses or the result of high flows), the correlation between the angle of slant of trees and the number of replicated genotypes present was also tested excluding the old stands. The positive correlation coefficients derived suggest that the greater the angle of slant of the tree, the greater the frequency of replicate genotypes in stands; this relationship

Table 6. Pearson's correlation coefficient of the number of replicated genotypes occurring in stands of different ages tested against certain descriptive parameters (angle of slant of trees, frequency of clumped growth and clump size)

\begin{tabular}{lcc}
\hline Parameters tested against number of replicated genotypes & Coefficient of correlation & $p$ \\
\hline Angle of slant of trees & & \\
Young + middle-aged + old & 0.034 & $n . s$. \\
Young + middle-aged & 0.096 & $<0.05$ \\
Young & 0.040 & $n . s$. \\
Middle-aged & 0.045 & $n . s$. \\
Old & 0.103 & $<0.1$ \\
Frequency of clumped growth & & \\
(no. of trees/stand displaying clumped growth) & & \\
Young + middle-aged + old & 0.013 & $n . s$. \\
Young & 0.064 & $n . s$. \\
Middle-aged & 0.234 & $<0.05$ \\
Old & -0.134 & $<0.1$ \\
Clump size (no. of stems/clump) & & \\
Young + middle-aged + old & 0.019 & $n . s$. \\
Young & 0.076 & $n . s$. \\
Middle-aged & 0.106 & $<0.1$ \\
Old & -0.125 & $<0.1$ \\
\hline
\end{tabular}


was, nevertheless, significant $(p<0.05)$ only when combining the young and middle-aged stands, or when considering the old stands independently $(p<0.1)$. A weak positive correlation was also observed between the frequency of trees in stands displaying clumped growth and the incidence of replicated genotypes; this relationship was, however, only found to be significant among middle-aged $(p<0.05)$ and old stands $(p<0.1)$. Clump sizes were similarly only found to be significantly correlated $(p<0.1)$ with the frequency of replicated genotypes in middle-aged and old stands. These positive correlation coefficients suggest that the greater the incidence of clumped growth in middle-aged and old stands and the greater the size of clumps where clumped growth occurs, the higher the expected frequency of replicate genotypes in middle-aged and old stands.

\section{Discussion}

\section{Clonal incidence and structure}

Replicated genotypes were detected in 20 out of the 30 P. nigra stands sampled along the study reach and represented $22 \%$ of all trees sampled. This result indicates an important contribution made by asexual regeneration strategies in the maintenance of $P$. nigra populations along the River Garonne, although levels of clonality in this population do not accord well with levels of clonality in P. nigra populations studied by Legionnet et al. (1996), Arens et al. (1998) and Smulders et al. (2002) who respectively reported replicated genotypes to comprise $3 \%, 83 \%$ or $42 \%$ of all trees sampled. These differences between studies can to some extent be expected, considering likely variations in resource availability and disturbance histories between respective study sites. They also highlight, however, the difficulty of comparing research on the same clonal species where sampling strategies and sampling intensities are not the same. Arens et al. (1998) and Smulders et al. (2002), for example, sampled all trees present in two populations $(29+42$ trees) and in a single population (120 trees), respectively making no distinction for ages of trees sampled. Legionnet et al. (1996), on the other hand, collected samples from all young trees (118 trees) present in a single uniform cohort and did not account for possible variations in levels of clonality among stands. In addition, none of the studies cited above offered any details on whether trees sampled displayed clumped growth, or minimum distances between sample trees. In this study, inclusion of stems comprising the clumped growth of a single genotype yielded a substantially higher estimate of the number of replicated genotypes per stand.

Concerning clonal structure, in this study replicate genotypes were most often found to occur as nearest neighbours ( $76 \%$ of the time) and formed 
relatively small, discrete units (i.e. 2-4 trees growing in close proximity to one another). This finding reflects the results of Legionnet et al. (1996), but differs from Arens et al. (1998) and Smulders et al. (2002), who reported substantially more replicates per $P$. nigra clone (i.e. up to 24 trees per clone) and noted some 'inter-mingling' of stems belonging to different clones. Despite these variations between studies, the fairly localised and continuous structure of clones in all studies suggests that reprouting following flood-training is a key mechanism by which asexual regeneration is initiated in this species even if not on the scale of other related species (e.g. Populus tremuloides ramet 'population' size of 81 ha as reported by Kemperman and Barnes, 1976).

Another important mechanism revealed in this study is the level of asexual recruitment via translocated fragments. The wide-scale sampling strategy adopted in this study permitted the identification of 11 replicate genotypes occurring in separate stands, revealing distances travelled downstream by vegetative fragments of up to $19 \mathrm{~km}$. Beismann et al. (1997) obtained similar evidence of successful long-distance dispersal of translocated fragments by the river $(>10 \mathrm{~km})$ in the woody sprouting riparian species Salix fragilis. Considering the relatively modest sample size in this study (450 trees) and the very small sample size of Beismann et al. (26 trees) with respect to the total number of trees present along respective study reaches, the probability of encountering replicate genotypes appears to be high. This suggests that the relative contribution of translocated fragments as a means of asexual regeneration and dispersal of genets is frequently underestimated for these and other woody riparian sprouting species and particularly among members of the Salicaceae family.

\section{Clonality and disturbance}

Important inter-stand variations in the frequency of clones were observed in young, middle-aged and particularly among old stands (Fig. 2a). These differences in levels of clonality among similar-aged stands are reflective of the unpredictable and patchy nature of flood disturbances and resource availability along the study reach, as was also indicated by variable degrees of floodtraining between stands of the same age group. Similar observations of within and between stand variations in relative proportions and distributions of sexual and asexual recruitment have been reported in other poplar species and these differences have similarly been linked to the spatially heterogeneous physical impacts of floodwaters (Rood et al., 1994; McKay, 1996; Gom and Rood, 1999).

In this study, sampling in different-aged stands inevitably meant that stands differed in terms of elevation and degree of exposure to floodwaters that served to extend the range of possible disturbance histories (and resource 
availabilities) at any given site. Young and middle-aged stands were the most exposed to flood disturbances, growing at low elevations on the floodplain on gravel bars, or on islands in early stages of development. The degree to which trees were bent over by floodwaters (angle of slant) and the degree of clumped growth displayed by trees served as an indication of disturbance in these age groups and could be related to the relative frequency of replicated genotypes found among stands. It was, however, not possible to use these indicators easily in older stands (e.g. leaning of trees could be attributed either to the forces of river flow, or to phototropic responses), or to easily compare levels of disturbance between different-aged stands. This was in part due to the different situations of trees in the various age groups on the floodplain and their variable vulnerability and physiological responses to flood disturbances (e.g. P. nigra saplings have high tolerance of lengthy periods of submergence and have both high stem flexibility and vigorous sprouting abilities in the face of strong currents and heavy sedimentation - Siebel and Blom, 1998; Siebel et al., 1998). More significantly, the indicators used provided only a snapshot of recent disturbance events and could not describe the history of disturbance experienced by a given stand of trees.

\section{Clonality and stand age}

Variations in the levels of clonality observed among P. nigra stands could also be attributed in part to stand age, explained by the different combined periods of exposure of young, middle-aged or old stands to successive flood disturbances and physiological differences between saplings/trees in the different age categories. Following an initial seedling recruitment event, genotypic diversity is apparently sustained for several years in young $P$. nigra stands that do not succumb to flood disturbances or a lack of vital resources. This study clearly demonstrated that even 4-7 years following initial seedling establishment, asexual recruitment remains relatively infrequent; i.e. clones were only found in half of all young stands sampled, with no more than a single replicate recorded among 'clonal' genotypes. Nevertheless, in accordance with Eriksson's Initial Seedling Recruitment (ISR) model (Eriksson, 1997), no further recruitment from seed at the stand level, and evidence of the vegetative expansion of remaining genotypes through flood-training resulted in a general decline in genotypic diversity as reflected by an increased encounter rate of replicated genotypes and a greater number of replicates per clone in middle-aged stands (8-11 years following seedling establishment). However, at this point there is a divergence from the ISR model predictions of a continued loss of genotypes within stands and increased clonal sizes that would otherwise lead to low overall levels of genotypic diversity in mature stands (14-20 years) - a trend that is supported by a number of empirical studies on herbaceous plant species 
(Aarssen and Turkington, 1985; Hartnett and Bazzaz, 1985; Maddox et al., 1989). The oldest stands revealed instead an overall recovery in genotypic diversity compared with middle-aged stands and this could be linked to a gradual die-off of sister ramets.

As a sizeable woody plant species, $P$. nigra stands are subject to self-thinning, a distinguishing characteristic of woody species that is almost unknown among clonal herbaceous and bryophyte species (Peterson and Jones, 1997; Cronberg, 2002). Die-off of sister ramets was a frequent observation in P. nigra stands of all age categories, leading to significant reductions in stand densities with stand age. It is nevertheless possible to imagine that where resources are abundant sister ramet survival might be greater, thus contributing to greater survival of replicate genotypes. This may have been the case in two adjacent mature stands along the River Garonne (stands 4 and 5; Fig. 1); i.e. stand density was very high in stand 4 , with no clones found among the 15 trees sampled, while stand 5 was much less densely populated and displayed not only more clumped growth, but three clones were also found among the 15 trees sampled.

Beyond the scale of the stand, recruitment in P. nigra populations can be said to adhere better to Eriksson's Repeated Windows of Opportunity model. While recruitment of P. nigra seedlings is not, or is only very rarely possible in the understory through the development of a gap, recruitment in adjacent freshly disturbed sites and along the edges of mature stands does occur, contributing fresh genetic material (Barsoum, 2002). The rate of influx of genetic material in this way will depend then on the availability, spatial scale, and stability of such zones of recruitment with respect to maturing stands. Stand thinning can be said to play a role in the meantime to limit the development of only a few large clones in stands and in this way maintain genotypic diversity; i.e. die-off of sister ramets ensures that clone sizes remain small, improving the chances of survival of multiple adjacent genotypes.

\section{Conclusions}

The conservation and management of effective population sizes in woody sprouting species such as $P$. nigra, requires a good understanding of the genotypic structure of respective populations and possible levels of variation in this structure in the spatial and temporal dimensions. This is important if dangerously low levels of genotypic diversity are to be prevented from developing (Rosetto et al., 1999). Our results indicate that for P. nigra significant variations in the incidence of clonality can exist within a single population, depending on the age of a stand and from one location to the next on the floodplain according to local disturbance histories. Translocated fragments 
were also revealed in this study to make an important contribution to recruitment dynamics in $P$. nigra and this mode of asexual recruitment should not be underestimated in clonal riparian species. To obtain a representative idea of genotypic diversity within a population, or among populations of a woody sprouting species, it is thus proposed that a hierarchical stratified sampling strategy is adopted (i.e. representation of genotypic diversity at the level of a stand, different age classes, different river reaches). Ecological and demographic indicators may provide first clues of probable levels of population genotypic diversity (Lefèvre et al., 2001), but as demonstrated in this study, genetic techniques adopted with an appropriate sampling strategy offer the clearest results.

\section{Acknowledgements}

We would like to thank Kirsten Skøt for running samples through the ABI 3100 Genetic Analyzer, Ann Cresswell for initiating contacts, Luc Lambs for his assistance with tree ring analysis, A. Vanden Broeck for helpful feedback on genetics alnalysis and Melanie Herteman for field work assistance. This research has been funded by the EU research contract: EVK1-CT-199900031FLOBAR2 (Floodplain Biodiversity and Restoration).

\section{References}

Aarssen, L.W. and Turkington, R. (1985) Within-species diversity in natural populations of Holcus lanatus, Lolium perenne and Trifolium repens from four different-aged pastures. J. Ecol. 73, 869-886.

Arens, P., Coops, H., Jansen, J. and Vosman, B. (1998) Molecular genetic analysis of black poplar (P. nigra L.) along Dutch rivers. Mol. Ecol. 7, 11-18.

Barsoum, N. (2001) Regeneration: requirements and promotion measures. In F. Lefèvre, N. Barsoum, B. Heinze, D. Kajba, P. Rotach, de S.M.G. Vries, and J. Turok (eds.) EUFORGEN Technical Bulletin: In Situ Conservation of Populus nigra. International Plant Genetic Resources Institute, pp. 16-24.

Barsoum, N. (2002) Relative contributions of sexual and asexual regeneration strategies in Populus nigra and Salix alba during the first years of establishment on a braided gravel bed river. Evol. Ecol. 15, 255-279.

Barsoum, N. and Hughes, F.M.R. (1998) Regeneration response of black poplar to changing river levels. In H. Wheater and C. Kirkby (eds) Hydrology in a Changing Environment, Vol. 1. John Wiley \& Sons, pp. 397-412.

Beismann, J.H., Barker, J.H.A. and Speck, T. (1997) AFLP analysis sheds light on the distribution of two Salix species and their hybrid along a natural gradient. Mol. Ecol. 6, 989-993.

Caraco, T. and Kelly, C.K. (1991) On the adaptive value of physiological integration in clonal plants. Ecology 72(1), 81-93.

Connell, J.H. (1978) Diversity in tropical rainforests and coral reefs. Science 199, 1302-1309.

Cooper, D.J., Merrit, D.M., Andersen, D.C. and Chimner, R.A. (1999) Factors controlling the establishment of Fremont Cottonwood seedlings on the upper Green River USA. Regul. Rivers: Res. Manage. 15, 419-40. 
Cottrell, J.E., Tabbener, H.E. and Forrest, G.I. (2002) Distribution of variation in British Black poplar: the role of human management. In: B.C. Van Dam and S. Bordacs (eds) Genetic Diversity in River Populations of European Black Poplar. Csiszár Nyomada Ltd., pp. 73-84.

Cronberg, N. (2002) Colonization dynamics of the clonal moss Hylocomium splendens on islands in a Baltic land uplift area: reproduction, genet distribution and genetic variation. J. Ecol. 90, 925-935.

De Steven, D. (1989) Genet and ramet demography of Oenocarpus mapora ssp. mapora, a clonal palm of Panamanian tropical moist forest. J. Ecol. 77, 579-596.

Dorken, M.E. and Eckert, C.G. (2001) Severely reduced sexual reproduction in northern populations of a clonal plant, Decodon verticillatus (Lythraceae). J. Ecol. 89, 339-350.

Ellstrand, N.C. and Roose, M.L. (1987) Patterns of genotypic diversity in clonal plant species. Am. J. Bot. 74: 123-131.

Engeman, R.M., Sugihara, R.T., Pank, L.F. and Dusenberry, W.E. (1994) A comparison of plotless density estimators using Monte Carlo simulation. Ecology 75(6), 1796-1779.

Eriksson, O. (1989) Seedling dynamics and life histories in clonal plants. Oikos 55, 231-238.

Eriksson, O. (1997) Clonal life histories and the evolution of seed recruitment. In H. De Kroon and J. Van Groenendael (eds) The Ecology and Evolution of Clonal Plants. Backhuys Publishers, pp. 211-226.

Eriksson, O. and Bremer, B. (1993) Genet dynamics of the clonal plant Rubus saxatilis. J. Ecol. 81, $533-542$.

Escavarge, N., Questiau, S., Pornon, A., Doche, B. and Taberlet, P. (1998) Clonal diversity in a Rhododendron ferrugineum L. (Ericaceae) population inferred from AFLP markers. Mol. Ecol. 7, 975-982.

Falińska, K. (1995) Genetic disintegration in Filipendula ulmaria: consequences for population dynamics and vegetation succession. J. Ecol. 83, 9-21.

Gom, L.A. and Rood, S.B. (1999) Patterns of clonal occurrence in a mature cottonwood grove along the Oldman River, Alberta. Can. J. Bot. 77, 1095-1105.

Guilloy-Froget, H. (2002) Evaluation des Conditions Favorables à l'Etablissement de Populus nigra et de Salix alba en Milieu Riverain. Ph.D. Thesis, Université Paul Sabatier, Toulouse, France.

Guilloy-Froget, H., Muller, E., Barsoum, N., Hughes, F.M.R. (2002) Dispersal, germination and survival of Populus nigra L. (Saliacaceae) in changing hydrologic conditions. Wetlands 22(3), 478-488.

Hartnett, D.C. and Bazazz, F.A. (1985) The genet and ramet population dynamics of Solidago canadensis in an abandoned old field. J. Ecol. 73, 407-413.

Held, M.E. (1983) Pattern of beech regeneration in the east-central United States. Bull. Torr. Bot. Club 110(1), 55-62.

Henderson, I. (1991) Alien invasive Salix spp. (willows) in the grassland biome of South Africa. S. zAfr. For. J. 157, 91-95.

Hermanutz, L.A., Innes, D.J. and Weis, I.M. (1989) Clonal structure of arctic dwarf birch (Betula glandulosa) at its northern limit. Am. J. Bot. 76, 755-761.

Iwasa, Y. and Kubo, T. (1997) Optimal size of storage for recovery after unpredictable disturbances. Evol. Ecol. 11, 41-65.

Jelinski, D.E. and Cheliak, W.M. (1992) Genetic diversity and spatial subdivision of Populus tremuloides in a heterogeneous landscape. Am. J. Bot. 79(7), 728-736.

Johnson, W.C. (1994) Woodland expansion in the Platte River, Nebraska: patterns and causes. Ecol. Monogr. 64(1), 45-84.

Keeley, J.E. (1977) Seed production, seed populations in soil, and seed production after fire for two cogeneric pairs of sprouting and non-sprouting chaparral shrubs. Ecology 58, 820-29.

Kemperman, J.A. and Barnes, B.V. (1976) Clone size in American aspens. Can. J. Bot. 54, 2603-2607.

Kreher, S.A., Fore, S.A. and Collins, B.S. (2000) Genetic variation within and among patches of the clonal species, Vaccinium stamineum L. Mol. Ecol. 9, 1247-1252.

Kruger, L.M., Midgley, J.J. and Cowling, R.M. (1997) Resprouters vs. seeders in South African forest trees; a model based on forest canopy height. Funct. Ecol. 11, 101-105. 
Kudoh, H., Shibaike, H., Wigham, D.F. and Kawano, S. (1999) Genet structure and determinants of clonal structure in a temperate deciduous woodland herb, Uvularia perfoliata. J. Ecol. 87, 244-257.

Lefèvre, F., Barsoum, N., Heinze, B., Kajba, D., Rotach, P., de Vries, S.M.G. and Turok, J. (2001) EUFORGEN Technical Bulletin: In Situ Conservation of Populus nigra. International Plant Genetic Resources Institute.

Legionnet, A., Faivre-Rampant, P., Villar, M. and Lefèvre, F. (1996) Sexual and asexual reproduction in natural stands of Populus nigra. Bot. Acta 110, 257-263.

Maddox, G.D., Cook, R.E., Wimberger, P.H. and Gardescu, S. (1989) Clone structure in four Solidago altissima (Asteraceae) populations: rhizome connections within genotypes. Am. J. Bot. 76, 318-26.

Malanson, G.P. and Trabaud, L. (1988) Vigour of post-fire re-sprouting by Quercus coccifera L. J. Ecol. 76, 351-365.

Mandujano, M.C., Montaña, C., Méndez, I. and Golubov, J. (1998) The relative contributions of sexual reproduction and clonal propagation in Opuntia ratrera from two habitats in the Chihuahuan Desert. J. Ecol. 86, 911-921.

McKay, S.J. (1996) The impact of river regulation on establishment processes of riparian black cottonwood. M.Sc. Dissertation, University of Washington, USA.

Minitab Inc. (2003) MINITAB User's Guide 2: Data Analysis and Quality Tools, Release 13 for Windows. Minitab Inc., Pennsylvania, USA.

Muirhead, C.A. and Lande, R. (1997) Inbreeding depression under joint selfing, out-crossing and asexuality. Evolution 51, 1409-1415.

Muller, E., Guilloy-Froget, H., Barsoum, N., Brocheton, L. (2002) Populus nigra L. en vallée de Garonne: legs du passé et contraintes du present. C. R. Biologies 325, 1-11.

Paciorek, C.J., Condit, R., Hubbell, S.P. and Foster, R.B. (2000) The demographics of resprouting in tree and shrub species of a moist tropical forest. J. Ecol. 88, 765-777.

Parker, K.C. and Hamrick, J.L. (1992) Genetic diversity and clonal structure in a columnar cactus, Lophocereus schottii. Am. J. Bot. 79(1), 86-96.

Peterson, C.J. and Jones, R.H. (1997) Clonality in woody plants: a review and comparison with clonal herbs. H. In De Kroon and J. Van Groenendael (eds) The Ecology and Evolution of Clonal Plants. Backhuys Publishers, pp. 263-289.

Pigott, C.D. (1993) Are the distributions of species determined by failure to set seed? In C. Marshall and J. Grace (eds) Fruit and Seed Production. Cambridge University Press, pp. 203-216.

Read, J. and Brown, M.J. (1996) Ecology of Australian Nothofagus forests. In T.T. Veblen, R.S. Hill and J. Read (eds) The Ecology and Biogeography of Nothofagus Forests. Yale University Press, pp. 131-181.

Read, R.A. (1958) Silvicultural characteristics of plains cottonwood. USDA Forest Service, Fort Collins, Col. Station Paper No. 33.

Rogers, D.L. (2000) Genotypic diversity and clone size in old-growth populations of coast redwood (Sequoia sempervirens). Can. J. Bot. 78, 1408-1419.

Rood, S.B., Hillman, C., Sanche, T. and Mahoney, J.M. (1994) Clonal reproduction of riparian cottonwoods in southern Alberta. Can. J. Bot. 72, 1766-1774.

Rosetto, M., Jezierski, G., Hopper, S.D. and Dixon, K.W. (1999) Conservation genetics and clonality in two critically endangered eucalypts from the highly endemic south-western Australian flora. Biol. Conserv. 88, 321-331.

Schmid, B. (1985) Clonal growth in grassland perennials. II. Growth form and fine-scale colonising ability. J. Ecol. 73, 809-818.

Shafroth, P.B., Scott, M.L. and Friedman, J.M. (1994) Establishment, sex structure and breeding system of an exotic riparian willow (Salix $\times$ rubens). Am. Midl. Nat. 132, 159-172.

Siebel, H.N. and Blom, C.W.P.M. (1998) Effects of irregular flooding on the establishment of tree species. Acta Bot. Neerl. 47(2), 231-240.

Siebel, H.N., Van Wijk, M. and Blom, C.W.P.M. (1998) Can tree seedlings survive increased flood levels of rivers? Acta Bot. Neerl. 47(2), 219-230. 
Smulders, M.J.M., van der Schoot, J., Ivens, B., Strome, V., Castiglione, S., Grassi, F., Bovenschen, J., van Dam, B.C. and Vosman, B. (2002) Clonal propagation in Black poplar (Populus nigra). In B.C. Van Dam and S. Bordacs (eds) Genetic Diversity in River Populations of European Black Poplar. Csiszár Nyomada Ltd., pp. 39-52.

Steiger, J., Gurnell, A.M., Ergenzinger, P. and Snelder, D. (2001) Sedimentation in the riparian zone of an incising river. Earth Surf. Process. Landforms 26(1), 91-108.

Strome, V., Vanden Broeck, A., Ivens, B., Smulders, M.J.M., Halfmaerten, D., van Slyken, J. and Boerjan, W. (2002) Ex-situ conservation of Black poplar in Belgium, the margin of the geographical distribution. In B.C. Van Dam and S. Bordacs (eds) Genetic Diversity in River Populations of European Black Poplar. Csiszár Nyomada Ltd., pp. 61-72.

Stuefer, J.F. (1998) Two types of division of labour in clonal plants: benefits, costs and constraints. Perspect. Plant Ecol. Evolut. Syst. 1(1), 47-60.

Tardif, J. and Bergeron, Y. (1999) Population dynamics of Fraxinus nigra in response to flood-level variations in Northwestern Quebec. Ecol. Monogr. 69(1), 107-125.

Van Dam, B.C. and Bordacs, S. (2002) Genetic Diversity in River Populations of European Black Poplar. Csiszár Nyomada Ltd., Budapest.

Van der Schoot, J., Pospíšková, M., Vosman, B. and Smulders, M.J.M. (2000) Development and characterisation of microsatellite markers in black poplar (Populus nigra L.). Theor. Appl. Genet. 101, 317-322.

Van Splunder, I., Coops, H., Voesenek, L.A.C.J., Coops, H., De Vries, X.J.A. and Blom, C.W.P.M. (1996) Establishment of alluvial forest species in floodplains: the role of dispersal timing, germination characteristics and water level fluctuations. Acta Bot. Neerl. 44(3), 269-278.

Widén, B., Cronberg, N. and Widén, M. (1994) Genotypic diversity, molecular markers and spatial distribution of genets in clonal plants, a literature survey. Folia Geobot. Phytotax., Praha 29, $245-263$.

Williams, G.C. (1975) Sex and Evolution. Princeton University Press, Princeton, New Jersey, USA.

Wilson, B.F., Patterson III, W.A. and O'Keefe, J.F. (1985) Longevity and persistence of alder west of the tree line on the Seward Peninsula Alaska. Can. J. Bot. 63, 1870-1875. 